\title{
The Psychiatric Bulletin: some background notes
}

\author{
Alan Kerr, co-editor, Psychiatric Bulletin
}

The British Journal of Psychiatry, the title it has enjoyed since 1963, can claim descent in direct line from three earlier journals, entitled in chronological order, The Asylum Journal from 1853; The Asylum Journal of Mental Science from 1855; and The Journal of Mental Science from 1858.

The Psychiatric Bulletin, however, is of more recent vintage, descended from a section of the lastnamed, but like the journal itself, it has over the years undergone several titular metamorphoses. The Bulletin "was for many years a miscellany, containing, besides news of the Medico-Psychological Association's meetings, comments on topical matters, reprints of press articles, obituary notices, and so on. Later, most of the short commentaries were transferred to a more prominent place in the Journal under the title 'Occasional Notes of the Quarter'. In course of time 'Notes and News' came to be filled almost entirely by official reports of Association meetings, and in 1936 it was decided to issue this section as a separate Supplement to members only" (Bulletin, 1977).

With the formation of the College in 1971, Alexander Walk proposed that there should be a newsletter, as an adjunct to the scientific contents of the journal. This was accepted, and Dr Walk played a major role in nursing the project through its formative stages, both as editor and as a one-man pressure group, persuading Council to give financial support to it at a time of great overall stringency. His personal authority and profound knowledge of the history of the College proved vital during the first ten years. News \& Notes, as the supplement was now known, aimed to reflect official College policy, as well as providing a forum for individual comment on issues of current interest. From July 1977, at the suggestion of Dr Thomas Bewley, the title became Bulletin of the Royal College of Psychiatrists, and then, from October 1988, Psychiatric Bulletin. As well as being circulated to members (currently 7,925) with each copy of the Journal, 239 copies are received by other subscribers in the United Kingdom and Ireland, and 54 circulated overseas. These trends are gradually upwards.

With an expansion in size from a mere 12 pages to the present 64 per issue, the scope of the content has broadened considerably. Regular features today are: interviews with distinguished colleagues and poli-

ticians; a lively correspondence column; conference reports (including the valued contributions from Geoffrey Wallis); an 'Historical Sketches' section, and an obituary section under the sensitive editorship of Henry Rollin. As the Psychiatric Bulletin has become established, the volume of original articles has markedly increased so that papers on clinical innovation and developments, medico-political topics, and educational, management, and ethical issues now appear in all issues and provide essential information on what is happening in the mental health services. A proportion of these are peerreviewed publications.

In satirical form, humour was found in the early years in Ezra the Scribe's column for which particular thanks go to Arthur Bowen (of the multidisciplinary cricket team), Henry Rollin, and Thomas Bewley.

Various editors have made distinctive contributions to its development. John Crammer, through his own highly readable contributions and the meticulous attention he gave to those of others, encouraged economy, clarity, and punch in writing. Hugh Freeman expanded its scope and international coverage, and he and Brian Barraclough have skilfully acted as two of the major interviewers. Special mention should be made of the influential part Sidney Bloch played during two distinct editorial periods. He initiated the Trainees' Forum section and the ethical column, and also played a major part in commissioning reports on psychiatry in other countries. The Bulletin has also been particularly well served by secretarial and administrative support within the Journal office. It is especially gratifying that Flora Peett, Alison Campbell, and Elaine Millen have, in addition to their administrative duties, each written articles for the Bulletin columns.

For the future, the Psychiatric Bulletin will continue to publish College thinking on mental health policy matters, as well as providing a forum for colleagues to discuss issues of mutual interest and concern. Increasingly, it is a journal in its own right, publishing important original work on developments in the mental health services.

\section{Reference \\ Bulletin of the Royal College of Psychiatrists, July 1977.}

